\title{
Latest Permian Peltasperm Plant From Southwest China and Its Paleoenvironmental Implications
}

\author{
Zhuo Feng ${ }^{1,2 *}$, Hai-Bo Wei ${ }^{1}$, Rong-Hui Ye ${ }^{3}$, Qun Sui ${ }^{1}$, Xu-Dong Gou ${ }^{1}$, Yun Guo ${ }^{1}$, Lu-Jun Liu ${ }^{4}$ \\ and Shi-Ling Yang ${ }^{5,6,7}$
}

${ }^{1}$ Institute of Palaeontology, Yunnan Key Laboratory for Palaeobiology, MEC International Joint Laboratory for Palaeobiology and Palaeoenvironment, Yunnan Key Laboratory of Earth System Science, Yunnan University, Kunming, China, ${ }^{2}$ Institute of Karst Geology, Chinese Academy of Geological Sciences, Guilin, China, ${ }^{3}$ School of Earth Sciences, Yunnan University, Kunming, China, ${ }^{4}$ Nanjing Institute of Geology and Palaeontology, Chinese Academy of Sciences, Nanjing, China, ${ }^{5}$ Key Laboratory of Cenozoic Geology and Environment, Institute of Geology and Geophysics, Chinese Academy of Sciences, Beijing, China, ${ }^{6}$ CAS Center for Excellence in Life and Paleoenvironment, Beijing, China, ${ }^{7}$ College of Earth and Planetary Sciences, University of Chinese Academy of Sciences, Beijing, China

\section{OPEN ACCESS}

Edited by: Shuzhong Shen,

Nanjing University, China

Reviewed by:

Stephen McLoughlin, Swedish Museum of Natural History,

Sweden

André Jasper,

Universidade do Vale do

Taquari - Univates, Brazil

*Correspondence: Zhuo Feng

zhuofeng@ynu.edu.cn

Specialty section: This article was submitted to Paleontology,

a section of the journal Frontiers in Earth Science

Received: 06 May 2020 Accepted: 15 September 2020 Published: 30 October 2020

Citation:

Feng Z, Wei HB, Ye RH, Sui Q, Gou XD, Guo Y, Liu LJ and Yang SL (2020) Latest Permian Peltasperm Plant From

Southwest China and Its

Paleoenvironmental Implications.

Front. Earth Sci. 8:559430.

doi: 10.3389/feart.2020.559430
A monospecific flora containing a peltasperm species, Germaropteris martinsii, is discovered from the uppermost Permian Kayitou Formation of Southwest China. The epidermal characteristics of G. martinsii from the South China Block are described for the first time on the basis of charcoalified specimens. The plant is characterized by small, leathery foliage with prominent papillate epidermal cells, and slightly sunken stomata. The stomatal apertures are covered by the long papillae of the surrounding subsidiary cells. The specific epidermal traits suggest that $G$. martinsii is a highly environmentally tolerant taxon that probably formed monospecific communities during the dramatic degradation of the peat-forming rainforest ecosystems. The frequent appearance of charcoalified leaves in the flora demonstrates that intense wildfires were prevalent at the time. The appearance and reflectance value (1.33\%) of these charcoalified leaves reveal that they were formed at temperatures of $450-500^{\circ} \mathrm{C}$ during brief surface fires. Our study indicates that the terrestrial ecosystems may have been frequently subjected to desiccation and was vulnerable to the spread of fires as a result of the end-Permian biotic crisis in the tropics of the eastern Tethys region.

Keywords: Germaropteris martinsii, wildfire, vegetation response, end-Permian mass extinction, Southwest China

\section{INTRODUCTION}

Peltasperms are a group of seed plants that have long been considered a typical component of the early Mesozoic vegetation (Taylor et al., 2009). Fossil evidence obtained during recent decades indicates that this group has a very wide spatiotemporal distribution during the late Paleozoic (Kerp, 1996; Kerp, 2000; Liu and Yao, 2000; Kerp et al., 2001; Baumgardner et al., 2016; Cai et al., 2019), with high diversity specifically in the Permian lowland (sub)tropics (DiMichele et al., 2005; Bercovici et al., 2015; Yu et al., 2015; Chu et al., 2019). It was found recently that peltasperms are more common and diverse in the Permian than previous thought (Kustatscher et al., 2014; Wang et al., 2014; Wan and Wang, 2015; Cai et al., 2019). Because the peltasperms were an exceptionally successful and diverse group that spanned the Permian and Triassic periods, they are particularly important for understanding how plants responded to the end-Permian terrestrial crisis. 

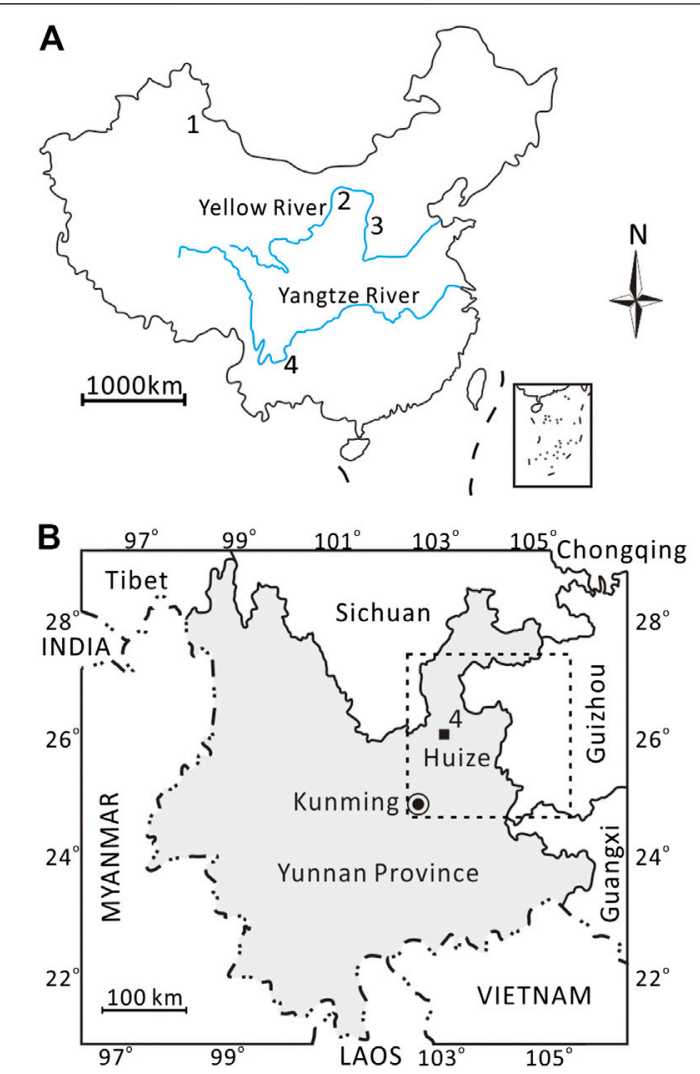

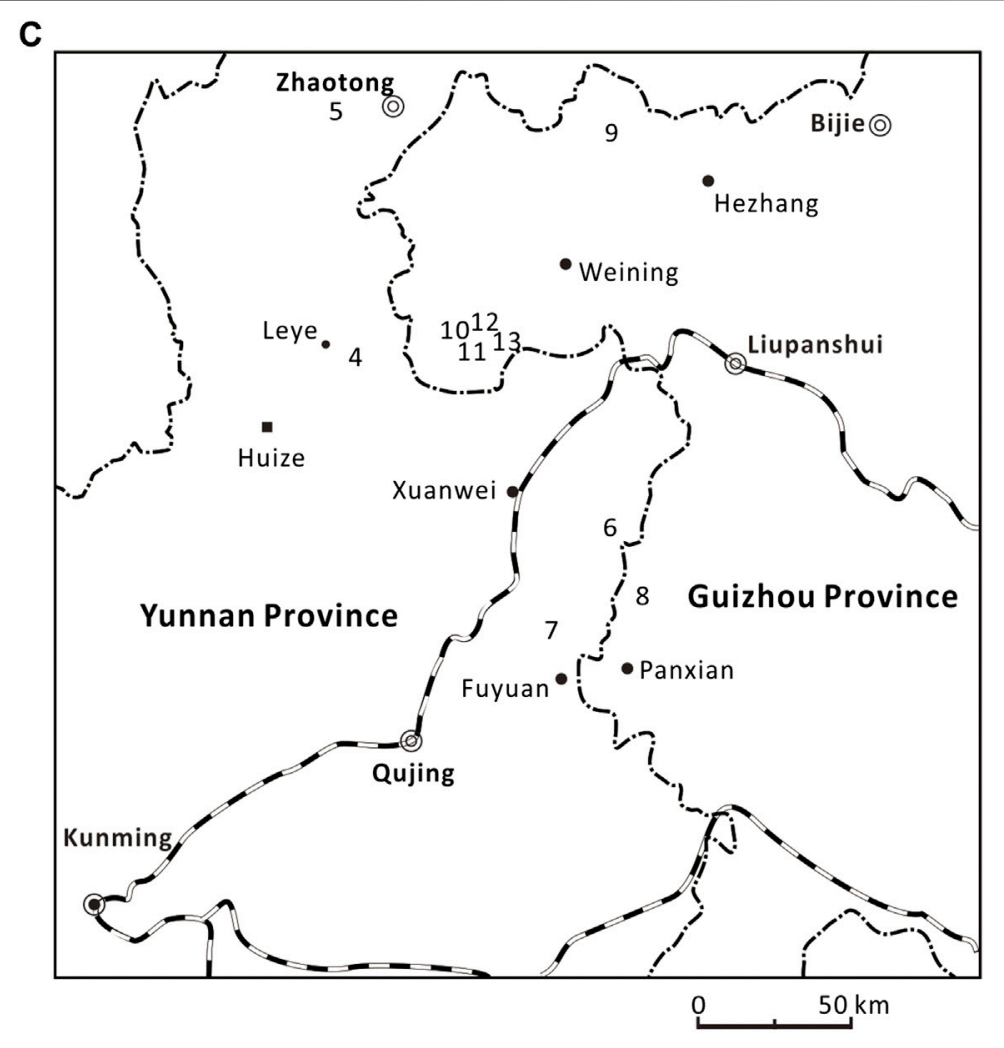

FIGURE 1 | Geographic maps (A-C) showing the Germaropteris martinsii localities in China. 1) Dalongkou (Xinjiang); 2) Baode (Shanxi); 3) Liulin (Shanxi); 4) Lubei (Yunnan); 5) Guanbachong (Yunnan); 6) Mide (Yunnan); 7) Housuo (Yunnan); 8) Tucheng (Guizhou); 9) Lengqinggou (Guizhou); 10) Chahe (Guizhou); 11) Jiucaichong (Guizhou); 12) Xiaohebian (Guizhou); 13) Jinzhong (Guizhou).

The fossiliferous Permian-Triassic transitional deposits, including the Xuanwei, Kayitou, and Dongchuan/Feixianguan formations, are exposed extensively in eastern Yunnan and western Guizhou provinces, Southwest China. The area is part of the southwestern margin of the South China Block and was located between the Khangdian "Oldland" and the Cathaysian landmass in the tropical eastern Tethys region during the Permian-Triassic interval (Bureau of Geology and Mineral Resources of Yunnan Province, 1996). The Kayitou Formation in this area represents the transitional deposits between the underlying coal-bearing beds of the Xuanwei Formation and the overlying red-beds of the Dongchuan/ Feixianguan Formation (Shen et al., 2011, Shen et al., 2019). Multi-disciplinary correlation investigations have constrained the Kayitou Formation to the Permian-Triassic interval, but there is no consensus on the precise age of the formation (Shen and Bowring, 2014; Yu et al., 2015). High-resolution biostratigraphic and geochemical analyses suggest that the Kayitou Formation is a diachronous lithostratigraphic unit ranging from the uppermost Permian to lowermost Triassic (Zhang et al., 2016; Shen et al., 2019). On the basis of detailed field observation across different sedimentological settings, the entire Kayitou Formation has recently been assigned to the uppermost Permian in the terrestrial sections but to the lowermost Triassic in the terrestrial-marine transitional sections (Feng et al., 2020).

The Cathaysia Flora, one of the four major floral realms during the late Paleozoic, is distributed mainly in what are now East and Southeast Asian countries (Feng, 2017). It is characterized by the highly diverse enigmatic gigantopterid plants; it is, thus, also called the Gigantopteris flora (Li, 1997). It was recently demonstrated that the Gigantopteris flora last appeared in the uppermost Xuanwei Formation in the terrestrial-marine transitional sections of Southwest China, where it was then completely replaced by herbland communities of isoetalean lycophytes (Feng et al., 2020). However, it remains unclear how the Gigantopteris flora disappeared across different environments and how the terrestrial ecosystems changed in response to the end-Permian biotic crisis.

Hundreds of impressed and charcoalified peltasperm leaves were collected from the Kayitou Formation of northeastern Yunnan and western Guizhou provinces, Southwest China. The charcoalified specimens from the terrestrial Lubei section of northeastern Yunnan Province preserve the epidermal characteristics in great detail. Our study sheds new light on the biological features of the peltasperm in the latest Permian and provides new insights into the terrestrial environment during the end-Permian terrestrial crisis. 

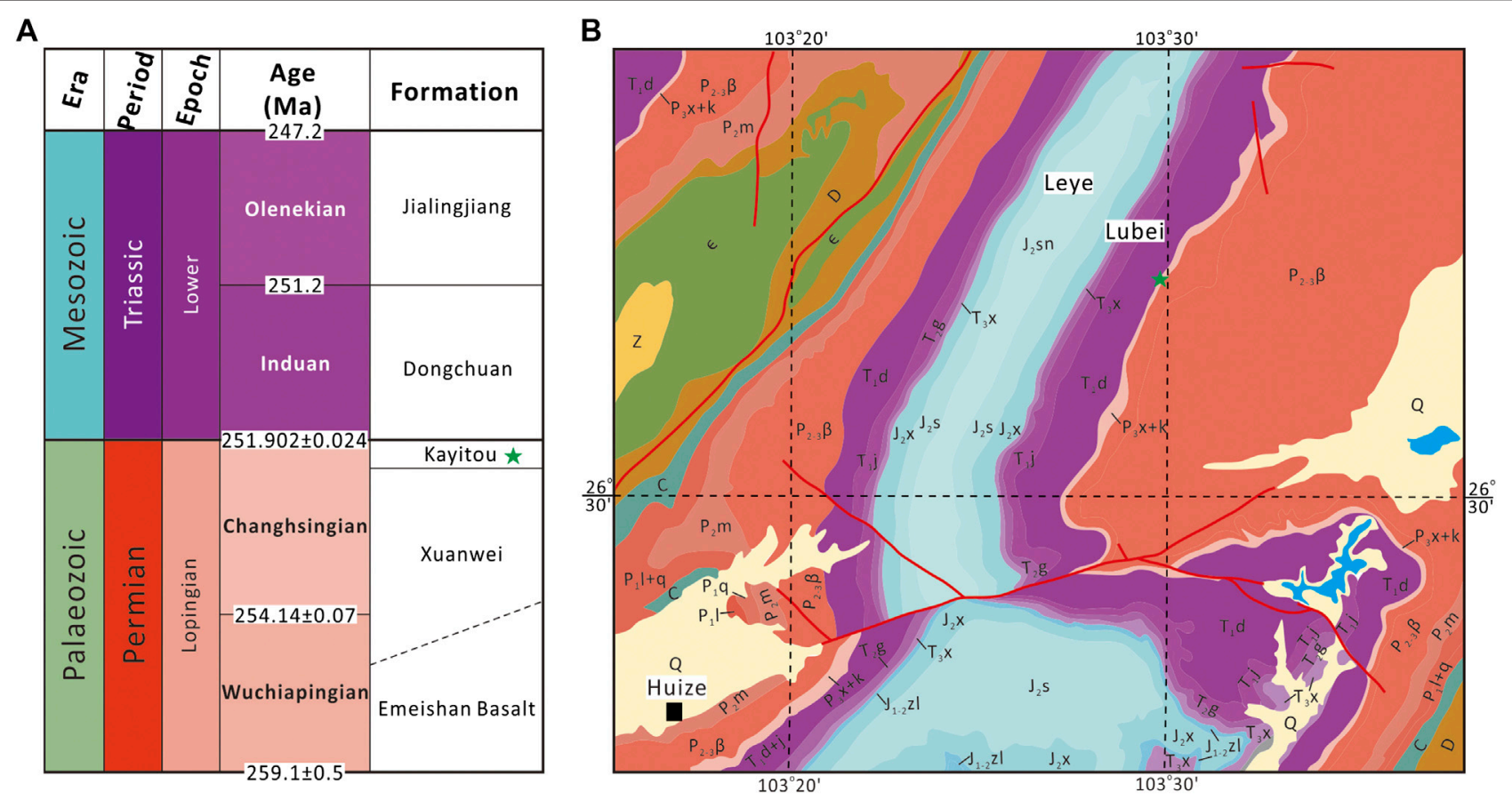

FIGURE 2 | Geological sequences (A) and geological map (B) of the Lubei section (asterisk) in northern Yunnan Province, Southwest China. Z, Neoproterozoic; є, Cambrian; D, Devonian; C, Carboniferous; $P_{1}$ l, Lower Permian Liangshan Formation; $P_{1}$ q, Lower Permian Qixia Formation; $P_{2} m$, Middle Permian Maokou Formation; $\mathrm{P}_{2-3} \beta$, Middle-upper Permian Emeishan Basalt; $\mathrm{P}_{3} \mathrm{x}$, Upper Permian Xuanwei Formation; $\mathrm{P}_{3} \mathrm{k}$, Upper Permian Kayitou Formation; $T_{1} \mathrm{~d}$, Lower Triassic Dongchuan Formation; $T_{1}$ j, Lower Triassic Jialingjiang Formation; $T_{2}$ g, Middle Triassic Guanling Formation; $T_{3} \mathrm{x}$, Upper Triassic Xujiahe Formation; $\mathrm{J}_{1-2} \mathrm{Zl}$, Lower-Middle Jurassic Ziliujing Formation; $\mathrm{J}_{2} \mathrm{x}$, Middle Jurassic Xiashaximiao Formation; $\mathrm{J}_{2} \mathrm{~s}$, Middle Jurassic Shangshaximiao Formation; $\mathrm{J}_{2} \mathrm{sn}$, Middle Jurassic Suining Formation; Q, Quaternary.

\section{MATERIALS AND METHODS}

Peltasperm leaves are common in the Kayitou Formation in the border region of Yunnan and Guizhou provinces, Southwest China. The fossil specimens described in this study were collected from the Lubei section of Leye Town, approximately $45 \mathrm{~km}$ north of Huize County in Qujing City, Yunnan Province (Figures 1A-C). In the Lubei section, the Kayitou Formation is approximately $9.4 \mathrm{~m}$ thick; it conformably overlies the upper Permian (Lopingian) Xuanwei (Hsuanwei) Formation and is overlain by the Lower Triassic Dongchuan Formation (Figures 2A,B). The Kayitou Formation is characterized by a dramatic shift in the lithofacies of the lacustrine-swamp or fluvial environment from yellowish gray mudstone, siltstone, and fine- to coarse-grained sandstone in the lowermost part, to gradually increasing maroon mudstones, with poorly sorted breccia and calcareous nodules in the uppermost part (Zhang et al., 2016). All specimens illustrated in this study were collected from a thin yellowish gray muddy siltstone bed in the upper part of the Kayitou Formation, associated with abundant conchostracans, ca. $9.1 \mathrm{~m}$ above the topmost coal of the Xuanwei Formation (Figures 3A-D) (Scholze et al., 2020).

The charcoalified peltasperm leaves and vascular fragments studied here were obtained by bulk maceration using hydrofluoric acid (HF). Samples were treated with $47 \%$ HF for several days, sieved, washed with diluted water, and then prepared for optical and scanning electron microscopy (SEM) investigations. Hand specimens were immersed in 100\% ethanol during macrophotography using a Nikon D3X camera with an AF-S Micro NIKKOR $105 \mathrm{~mm}$ 1:2.8G ED lens; polarized filters were mounted on both the light source and camera lens. Optical examination and photomicrography were performed using a Leica M 205 C stereomicroscope equipped with a Leica DFC 500 digital camera. SEM was performed using an FEI QUANTA 650 Field Emission Gun; before the SEM examination, the specimens were sputter-coated with gold.

The charcoalified leaf specimens selected for reflectance measurement were treated as follows. Indi charcoal fragments were embedded in resin and polished; they were then studied using standard techniques for coal petrography under a Zeiss AXIO Imager A2m microscope attached to a Zeiss AxioCam MRc5 camera. The reflectance was measured under Zeiss immersion oil (refractive index of 1.518 at $23^{\circ} \mathrm{C}$ ) using the $\times 100$ objective lens illuminated by a $546 \mathrm{~nm}$ light source. The instrument was calibrated against two standards, i.e., sapphire $\left(R o_{\text {,mean }}=0.589\right)$ for low reflecting samples and cubic zirconium $\left(R o_{\text {,mean }}=3.18\right)$ for high reflecting samples. The reflectance was measured at $\geq 10$ points per sample to calculate $R o_{\text {,mean }}$ and the standard deviation of $R o_{\text {,mean }}$ using the TIDAS CCD MSP 200 software.

The specimens and digital photographs are housed in the Palaeobotanical Collections of the Institute of Palaeontology, 


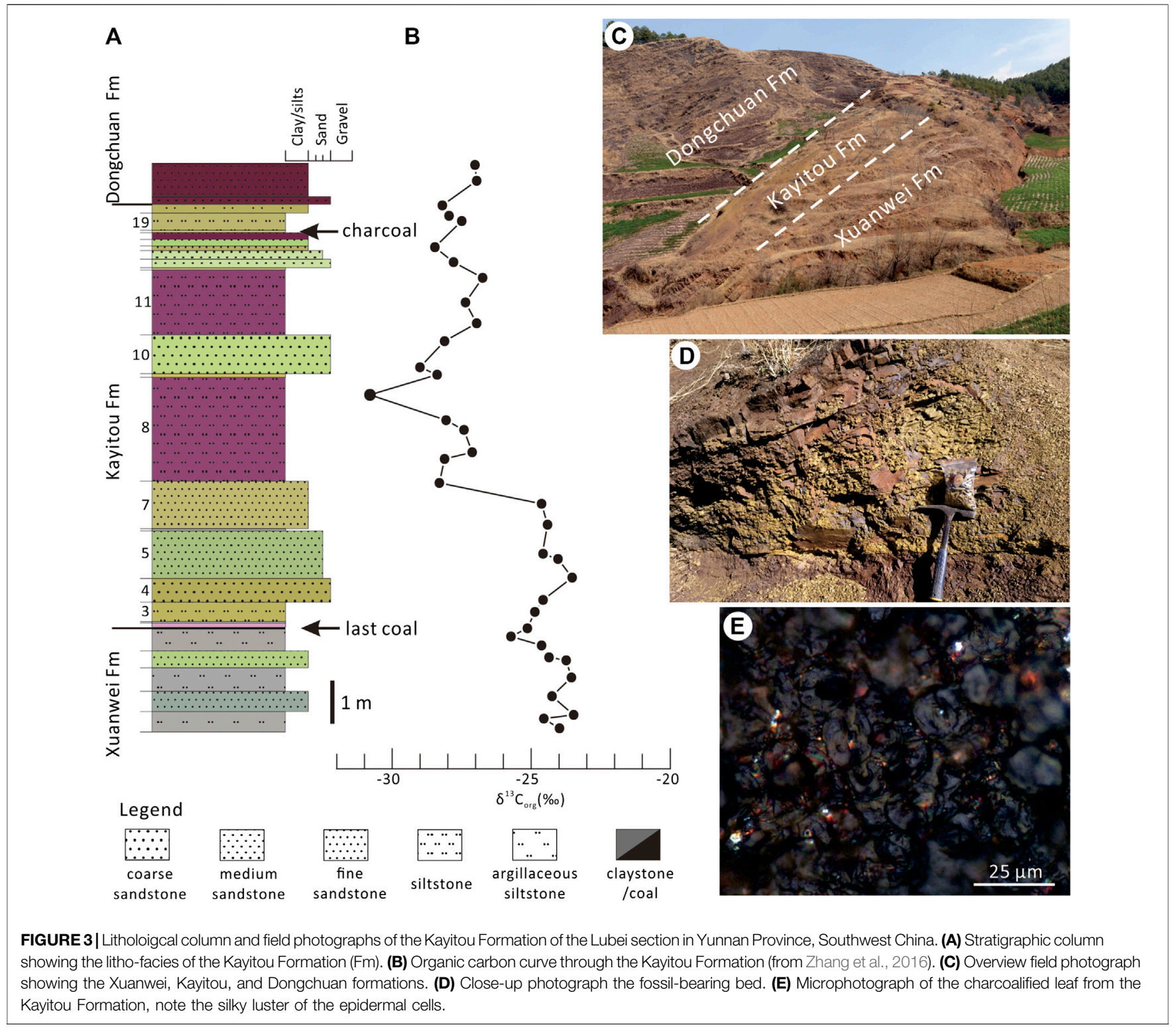

Yunnan University, Kunming, China, under catalog numbers YNUPB10110-120.

\section{RESULTS}

\section{Morphology and Anatomy of Germaropteris martinsii From the Kayitou Formation}

More than 100 Germaropteris martinsii leaves were investigated in this study. The following description is based on both impressed (Figure 4) and charcoalified (Figure 5) specimens. The penultimate pinnae were rarely obtained (Figures $4 \mathbf{A}, \mathbf{B}$ ). The most complete penultimate pinna is $8 \mathrm{~mm}$ long and features a $1.5-\mathrm{mm}$-wide rachis. The frond rachis is commonly $0.5-1 \mathrm{~mm}$ wide and bears at least six ultimate pinnae up to $5 \mathrm{~mm}$ long, with numerous sub-oppositely to alternately arranged small pinnules.

Ultimate pinnae were more commonly observed and showed considerable variation in shape and dimensions. The primary rachides are overtopped, pseudo-dichotomized, or double (pseudo-) dichotomized by pinnules in the apices (Figures 4C-E,G-I). The pinnules are of the alethopteroid type and are up to $2 \mathrm{~mm}$ long and $1 \mathrm{~mm}$ wide; they gradually decrease in size distally and basally (Figure 4F). The pinnules are entire-margined, semi-circular, ovate, broadly triangular to linguiform, and broadly attached or slightly decurrent with a rounded apex. The pinnules in the smaller pinnae are densely arranged and generally attached alternately (Figure 4J), but in the larger pinnae, they are loosely spaced and attached sub-oppositely (Figure 4K). Venation was not observed owing to the thick and leathery nature of the pinnules. 

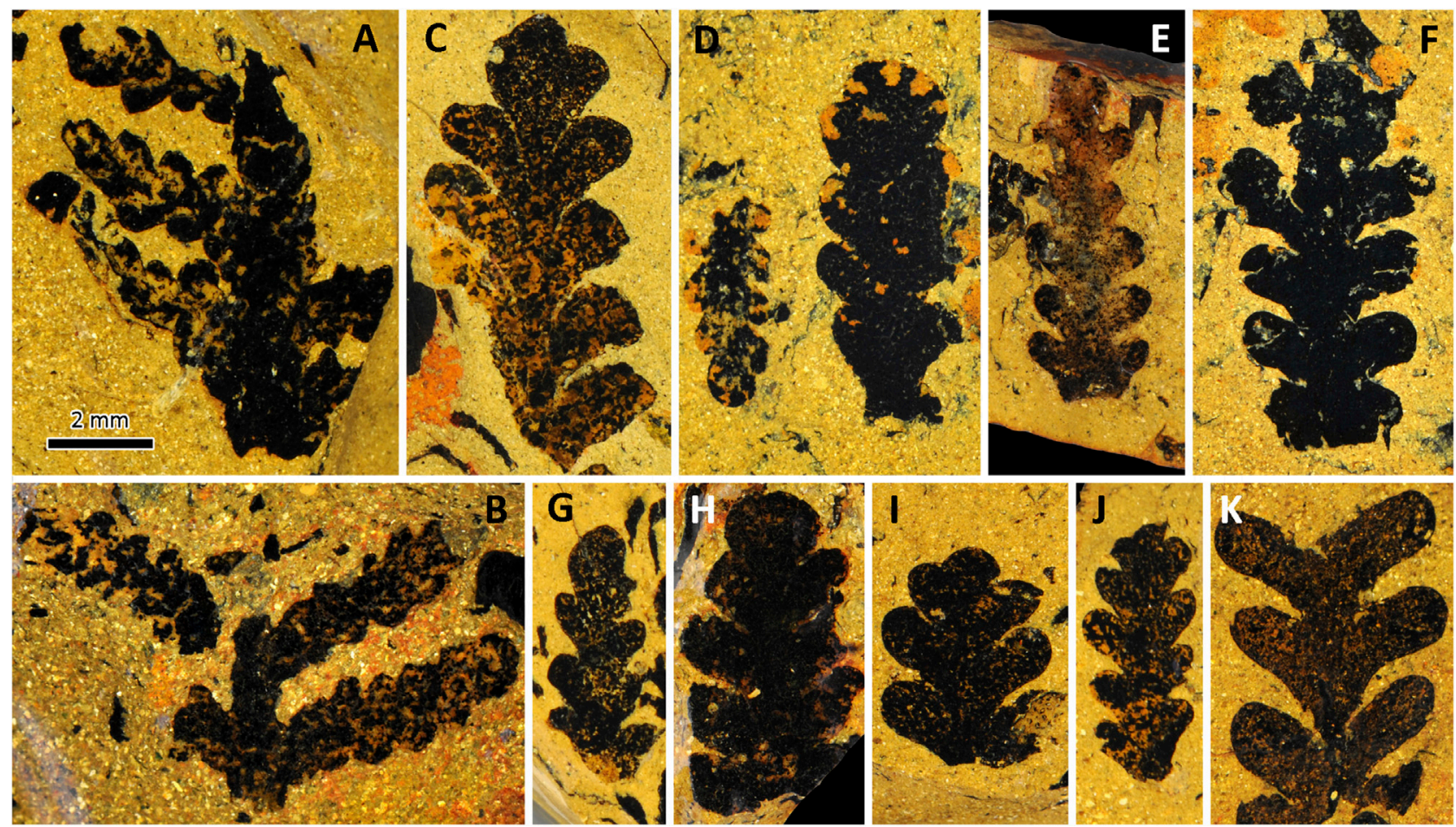

FIGURE 4 | Light photographs of Germaropteris martinsii from the upper Permian Kayitou Formation of Southwest China. (A,B) Penultimate fronds showing alternately attached ultimate pinnae. (C-E,G-I) Ultimate pinnae showing the overtopped apices in different modes. (F) Ultimate pinna; note that the pinnules gradually decrease in size distally and basally. (J) Immature ultimate pinna showing tightly arranged and alternately attached pinnules. (K) Relatively mature ultimate pinna showing loosely spaced and sub-oppositely attached pinnules. Scale bar applies to all images. Specimen no. YNUPB10110-120.

The epidermal features of the charcoalified specimens were observed (Figures 5A-D). The leaves are amphistomatic with irregularly scattered and sunken stomatal complexes (Figure 5E). More stomata appear in the abaxial (lower) surface than in the adaxial (upper) surface. The epidermal cells on both the rachis and pinnules possess papillae, although in some cases the epidermal cells on the pinnule margin are not papillate. The epidermal cells are elongated longitudinally on the rachis (Figure 5F) but have isodiametric polygonal forms on the pinnules (Figure 5G). The stomata on the rachis are slightly elongated longitudinally and are somewhat larger in diameter than those on the pinnules. The diameter of the normal epidermal cells appears to be smaller at the margin of the pinnule (Figure $\mathbf{5 H}$ ). The stomatal aperture is protected by the overarching papillae of the five or six (rarely four, seven, or eight) subsidiary cells on both the adaxial and abaxial surfaces of the pinnule (Figures 5I-L). The subsidiary cells are slightly smaller than the normal epidermal cells and are trapezoid to polygonal. The stomatal complexes never share subsidiary cells but can be closely spaced. Hairs and hair bases were not observed.

From the same leaf-bearing bed, black colored and silky lustered wood fragments were recovered. Under SEM, well preserved anatomical details (Figure 5M), including homogenized cellwalls of the tracheid elements (Figure $\mathbf{5 N}$ ), and uni- to biseriate pits on the radial tracheid walls (Figures 50,P).

\section{Reflectance Analysis of Germaropteris martinsii From the Kayitou Formation}

The fracture of the leaf specimens has a typical silky luster when examined by reflected light (Figure 3E). The random reflectance values of a total of 125 analysis points on eight charcoalified leaf specimens ranged from $0.94 \%$ to $1.64 \%$, with a mean value of 1.33\% (Table 1).

\section{COMPARISON}

The fossil leaves described here are characterized mainly by alethopteroid-type pinnules with amphistomatic stomata, which are the most typical feature of peltasperm foliage (Poort and Kerp, 1990; Vörding and Kerp, 2008). Fragmentary leaf impressions were previously reported from the Kayitou Formation in eastern Yunnan and western Guizhou provinces, and were assigned to Peltaspermum cf. martinsii (Harris) Poort et Kerp or Lepidopteris cf. martinsii (Chen et al., 2011; Bercovici et al., 2015; Yu et al., 2015; Chu et al., 2016; Chu et al., 2019). Although no intercalary pinnules were observed, the macromorphology, and in particular the epidermal features of the pinnae under consideration, support an assignment to Germaropteris (=Peltaspermum) martinsii (Kustatscher, Kerp et Van Konijnenburg-van Cittert, 2014 (Please see Appendix)). 

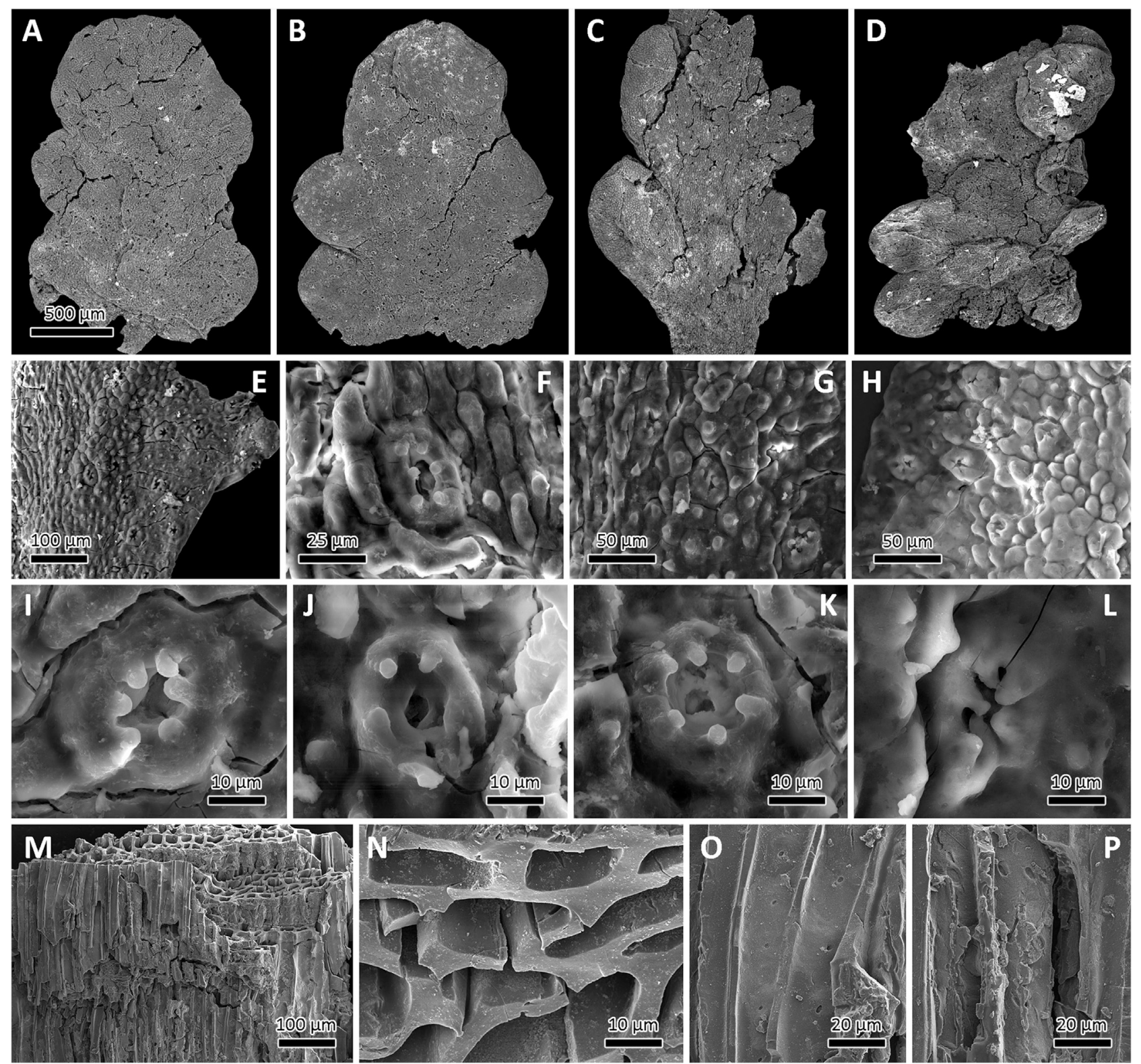

FIGURE 5 | Scanning electron microscopy images of epidermal anatomy of Germaropteris martinsii from the upper Permian Kayitou Formation of Southwest China. (A-D) Charcoalified specimens showing various morphologies from less mature to mature pinnae. (E) Epidermal structure of the rachis and pinnule, from left to right; note the scattered stomatal complexes. (F) Slightly elongate stomatal complex and conspicuously longitudinally elongated epidermal cells on the rachis. (G) Middle part of a pinnule showing stomatal complex with a rounded outline; note the prominent papillated epidermal cells. (H) Margin of a pinnule showing the less prominent papillate epidermal cells. (I-L) Stomatal complexes; note the stomatal aperture overarched by the long papillae of the surrounding subsidiary cells. (M) Overview of charred wood fragment collected from the studied level. (N) Detail of (M) showing homogenized cell walls. (O) Detail of (M) highlighting the cell-wall homogenization and uniseriate pits on the radial tracheid walls. (P) Detail of (M) highlighting the cell-wall homogenization and biseriate pits on the radial tracheid walls. Scale bar in (A) also applies to (B-D).

Germaropteris martinsii is identified by the distinctive leaf and consistently co-occurring ovuliferous organs, which were previously assigned to the "natural" species Peltaspermum martinsii (Poort and Kerp, 1990). This species is recognized by its small alethopteroid-type pinnules with unique stomatal complexes and radially symmetrical, peltate reproductive organs with numerous seeds attached to the lower side of the ovuliferous discs. Germaropteris martinsii has been widely documented in the upper Permian of Eurasia, for example, in Germany (Kurtze, 1839; Germar, 1840; Geinitz, 1862; Schweitzer, 1962; Poort and Kerp, 1990), England (Stoneley, 1958), China (Wang, 1985; Wang and Wang, 1986; Chen et al., 2011; Zhang et al., 2012; Bercovici et al., 2015; Yu et al., 2015; Chu et al., 2016; Chu et al., 2019; Cai et al., 2019), and Italy (Kustatscher et al., 2014). Leaf 
TABLE 1 | Reflectance data of the charcoalified Germaropteris martinsii leaves from the upper Permian Kayitou Formation of Southwest China.

\begin{tabular}{lccccc} 
Sample & Analyzed points & MAX (\%) & MIN (\%) & AV (\%) & SD (\%) \\
\hline 1 & 15 & 1.38 & 0.94 & 1.02 & 0.04 \\
2 & 17 & 1.51 & 1.33 & 1.43 & 0.05 \\
3 & 17 & 1.50 & 1.07 & 1.29 & 0.05 \\
4 & 16 & 1.37 & 1.27 & 1.33 & 0.03 \\
5 & 19 & 1.64 & 1.37 & 1.56 & 0.05 \\
6 & 16 & 1.33 & 0.96 & 1.24 & 0.04 \\
7 & 11 & 1.50 & 1.30 & 1.39 & 0.04 \\
8 & 14 & 1.35 & 1.23 & 1.28 & 0.03 \\
Total & 125 & - & - & 1.33 & -
\end{tabular}

MAX, Maximum; MIN, Minimum; AV, Average Value; SD, Standard Deviation.

impressions assigned to Germaropteris martinsii were recently reported from the lower Permian in west Texas, the United States (Baumgardner et al., 2016).

The macromorphology of the leaves studied here shows considerable variation from the larger to the smaller pinnules, but it falls within the variation range of Germaropteris martinsii (Poort and Kerp, 1990; Vörding and Kerp, 2008; Kustatscher et al., 2014). The epidermal structure of the leaves also has a wide range of variation. The epidermal cells on the rachis have longitudinally elongate rectangular shapes, whereas those on the pinnules are more or less isometrically polygonal. The epidermal cells within a single pinna are either papillate or non-papillate, although the papillae on the subsidiary cells are conspicuously longer than those on the normal epidermal cells. The papillae of the epidermal cells are more prominent in the middle portion of the pinnules than in the basal and distal portions. Note that no epidermal swelling was observed in our specimens.

The epidermal structure of Germaropteris martinsii in China was first described from the lower-middle part of the Sunjiagou Formation (upper Permian) in Liulin in Shanxi Province, North China (Wang and Wang, 1986). According to the presence of papillae and epidermal swellings and the size of the pinnules, the cuticular leaf fragments have been assigned to three species, i.e., Callipteris martinsii, C. papillosa, and C. lobulata (Wang and Wang, 1986). However, a thorough comparative study of "Peltaspermum" martinsii indicated that the size and density of the papillae can vary within a single pinna; in some cases, papillae are generally restricted to the subsidiary cells, whereas the normal epidermal cells are non-papillate, or papillae can be completely absent (Poort and Kerp, 1990). The pinnule morphology and epidermal structure are strongly related to the position of the pinnules in the frond and the growth stage of the frond; therefore, all three species from Liulin were considered synonymous with Germaropteris (Peltaspermum) martinsii (Poort and Kerp, 1990; Kustatscher et al., 2014).

Two small ultimate pinnae assigned to Lepidopteris baodensis have been documented with cuticles from the lower part of the Sunjiagou Formation in Baode, Shanxi Province (Zhang et al., 2012). Except for the frequent appearance of epidermal swellings with various shapes on the rachis and the pinnules, the anatomical structures of the Baode specimens are homologous to those of the material studied here. The palynological assemblage indicates that the Sunjiagou Formation in Baode was formed in a semi-arid to arid environment (Liu et al., 2011; Liu et al., 2015). The epidermal swellings in the Baode specimens were interpreted as the ecophysiological responses of the plant in a dry environment (Zhang et al., 2012); thus, they should not be regarded as a diagnostic feature.

Additionally, Lepidopteris is a generic name for peltasperm foliage that shows strict pecopteroid pinnules with pinnate venation. Although few species exhibit forked fronds (i.e., $L$. callipteroides, Retallack, 2002) and rounded pinnule apices (i.e., L. africana, Holmes and Anderson, 2005), Lepidopteris species generally possess very regular monopodial fronds with an acute frond apex and acute pinna apices (Harris, 1937; Townrow, 1956; Townrow, 1960; Stanislavsky, 1976; Anderson and Anderson, 1989; Goman'kov, 2006). Lepidopteris generally has slightly triangular, entire-margined pinnules with clear pinnate venation. By contrast, Germaropteris has rather irregular, in some cases bifurcated, commonly apically overtopping pinnules. In our opinion, Lepidopteris baodensis should be synonymized with Germaropteris martinsii owing to its typical alethopteroid-type pinnule architecture and the epidermal characteristics.

As is typical of Germaropteris martinsii, the venation of the current specimens is not recognizable. The lack of clear venation is due to the thick, leathery nature of the leaves and the relatively thick cuticles; it is considered to indicate a relatively dry habitat (Poort and Kerp, 1990). The charcoalified peltasperm foliage studied here shows highly inflated structures, which unequivocally reflect the leathery nature of the pinnules. Lithofacies analysis in the study region suggested a gradual change from a swampy peat-forming environment below the peltasperm-bearing bed to a fluvial system with at least seasonally dry conditions that yielded the current peltasperm leaves (Zhang et al., 2016).

\section{PALEOECOLOGICAL IMPLICATIONS}

The presence of fossil charcoal is considered direct evidence for wildfires in the distant geological past (Scott and Jones, 1994; Scott, 2010). The late Permian is the most crucial time interval for dramatic biodiversity and ecological changes in both the marine and terrestrial ecosystems during Earth's history (Erwin, 2006; Wignall, 2015). Our understanding of late Permian wildfire activity has been greatly increased in the last few years by extensive records of fossil charcoals (inertinites) from Australia (Glasspool, 2000; McLoughlin et al., 2019; Vajda et al., 2020), North China (Wang and Chen, 2001), Germany (Uhl and Kerp, 2003), Jordan (Uhl et al., 2007), the Canadian High Arctic (Grasby et al., 2011), South America (Jasper et al., 2011), South China (Shen et al., 2011; Shen et al., 2011; Shao et al., 2012; Zhang et al., 2016; Chu et al., 2020), India (Jasper et al., 2012; Jasper et al., 2016), Italy (Uhl et al., 2012), Russia (Hudspith et al., 2012), and the South Pole (Holdgate et al., 2005; Mays et al., 2020). Our material was obtained from the terrestrial Kayitou Formation, the age of 
which was recently tied to the Changhsingian by high-precision geochronological data (Shen et al., 2011; Zhang et al., 2016; Shen et al., 2019). Therefore, the charcoalified peltasperm leaves studied here provide new insights into the terrestrial crisis during the end-Permian mass extinction interval.

Charcoalified plant debris (mainly very tiny vascular fragments) has been recognized in a sandstone bed in the topmost part of the Kayitou Formation in Yunnan and at time-equivalent horizons in other locations in South China (Shen et al., 2011; Zhang et al., 2016). Although the taxonomic affinities of these plant remains are obscure, the occurrence of these charcoals indicates widespread wildfire activity during the latest Changhsingian in South China. To our knowledge, no charcoalified leaves have been documented from the Permian of South China to date. The appearance of sequential charcoal horizons in both the lower-middle and topmost portions of the Kayitou Formation may represent evidence for widespread and frequent wildfires during the accumulation of the Kayitou Formation in Southwest China.

Laboratory experiments in which extant plant samples were charred demonstrated that the mean random reflectance of a charcoal is strongly correlated with its formation temperature (Ascough et al., 2010). Although most of the previous proxies have been obtained by charring wood samples, experimental charring of fern leaves reinforced the relationship between the reflectance and the formation temperature (McParland et al., 2007). Because the reflectance values of charcoals and their formation temperatures are positively correlated (Jones et al., 1991; Scott and Glasspool, 2005; Scott and Glasspool, 2007; Glasspool and Scott, 2013), the reflectance values of fossil charcoal specimens have been widely applied to reconstructions of paleofire temperatures and paleofire types (Bodí et al., 2014; Glasspool et al., 2015).

After charring extant fern samples, McParland et al. (2007) concluded that 1) the visible reflectance is generated by charring at $300^{\circ} \mathrm{C} ; 2$ ) cell wall layers are homogenized at $350^{\circ} \mathrm{C}$; and 3) charcoal formed at $350^{\circ} \mathrm{C}$ becomes increasingly fragile; fragmentation is notable at a formation temperature of $500^{\circ} \mathrm{C}$ and becomes increasingly severe with increasing charring temperature. The average random reflectance of the current peltasperm leaf samples is $1.33 \%$. Charcoals with this reflectance would not have been formed at temperatures lower than $450^{\circ} \mathrm{C}$, according to the experimental data of McParland et al. (2007). The current charcoal specimens are relatively large (up to several millimeters), which may suggest that the formation temperature could not have been higher than $500^{\circ} \mathrm{C}$.

The morphology of the current charcoalified peltasperm leaves indicates that they probably formed during brief surface fires and had a limited transportation history. Field observations show three wildfire types, specifically, surface, crown, and ground fires, which have different temperatures and products in the vegetation under a fire regime (Scott et al., 2000; Scott, 2009). Our charcoalified leaves would probably have been formed during brief surface fires, like those in modern heathlands, where the temperatures are approximately $400-500^{\circ} \mathrm{C}$ (Scott et al., 2000; Scott, 2010).
Very few other plant fragments with calamitalean axes and fern foliage have been found in the charcoal-bearing bed in addition to the frequently appearing peltasperm leaves, suggesting that peltasperm leaves were probably the predominant fuel source for combustion. Therefore, the charcoalified plant remains found in the Kayitou Formation may have been derived from a low-diversity sclerophyllous vegetation forming a savanna- or prairie-like ecosystem; these are among the most fire-prone ecosystems today (Bond and Keeley, 2005; Retallack, 2018). Considering their completeness and exquisite anatomical detail, the charcoalified peltasperm leaves studied here may have been transported locally by wind, or more probably by low-energy water transport through overland flow.

Wildfires typically occur when environmental temperatures are high (Scott, 2009; Scott, 2010). The Permian-Triassic transition was a time of rapid global temperature increase (McElwain and Punyasena, 2007; Joachimski et al., 2012; Su et al., 2012; Romano et al., 2013). The higher temperatures could have been produced a much more arid (seasonal dry) environment with dynamic climate conditions. The resulting progressive degradation of the environment is thought to have lead to the ultimate collapse of terrestrial ecosystems (Benton and Newell, 2014; Cui and Kump, 2015; Grasby et al., 2015; Wignall, 2015). The widespread charcoals throughout the Kayitou Formation may reflect the response of the terrestrial ecosystem to the increasingly arid environment, which triggered frequent wildfires during the latest Permian in Southwest China.

Notable physiological changes in marine species have been widely recognized in the unstable marine ecosystems produced by the end-Permian mass extinction event (Knoll et al., 2007). Many of the abnormalities recognized in the sporomorphs from the transitional Permian-Triassic deposits are interpreted to be the plants' response to deteriorating environmental conditions (Hochuli et al., 2017; Benca et al., 2018). The leathery nature of Germaropteris martinsii may not necessarily be an ecophysiological adaption to the increased aridity of the terrestrial environment, but this specialized feature likely increased the survival of this specific plant clade during the catastrophic environmental change.

Wildfire plays a pivotal role in shaping terrestrial ecosystems (Bowman et al., 2009) and in the evolutionary history of land plants (Bond and Scott, 2010; Midgley and Bond, 2013; Yan et al., 2016; Pausas and Bond, 2020). Charcoal records show that wildfires have been driving the evolution of global vegetation since the invasion of land by plants some 400 million years ago (Glasspool et al., 2004; Glasspool et al., 2015). The latest Permian is a crucial time interval in which a rapid collapse of the Gigantopteris flora in the eastern Tethys region is documented (Feng et al., 2020). The peltasperm Germaropteris initially appeared during the early late Permian in the Gigantopteris flora (Wang, 1985). However, during the dramatic collapse of the Gigantopteris flora, Germaropteris remained as a prominent relic and became an opportunistic survivor owing to its specialized traits. 
Maceral composition analysis of the studied region shows that the inertinite content increased from the bottom to the topmost part of the upper Permian coals, indicating increased wildfire activity during the late Permian (Shao et al., 2012), which would accelerate the degradation of terrestrial ecosystems and would be partially responsible for the disappearance of the peat-forming rainforest ecosystems. Sedimentological features indicate that the peltasperm studied here probably grew on uplands or in the floodplains of rivers, where it formed heathland-like vegetation communities; the habitat was perhaps frequently subjected to desiccation and, therefore, vulnerable to the spread of fire. We tentatively speculate that the intense wildfire events recorded in the Kayitou Formation indicate increasing degradation of the terrestrial ecosystems in Southwest China during the latest Permian.

\section{CONCLUSIONS}

This is the first report of the leaf anatomy of a peltasperm plant from the Permian of the South China Block. The common occurrence of charcoalified Germaropteris martinsii in the Kayitou Formation reveals intense wildfire events during the latest Permian in Southwest China, where peltasperms formed patches of monospecific vegetation ecosystems during the dramatic distributional contraction of the Gigantopteris flora. The reflectance values indicate that the charcoalified G. martinsii leaves were formed during brief surface fire event(s) at temperatures of $450-500^{\circ} \mathrm{C}$. The leathery leaves of G. martinsii likely enhanced its survival during the collapse of terrestrial ecosystems during the end-Permian biotic crisis.

\section{REFERENCES}

Anderson, J. M., and Anderson, H. M. (1989). Palaeoflora of southern Africa. Molteno formation (Triassic). Gymnosperms (excluding dicroidium). Rotterdam/Brookfield: A. A. Balkema, Vol. 2, 567.

Ascough, P. L., Bird, M. I., Scott, A. C., Collinson, M. E., Cohen-Ofri, I., Snape, C. E., et al. (2010). Charcoal reflectance measurements: implications for structural characterization and assessment of diagenetic alteration. J. Archaeol. Sci. 37, 1590-1599. doi:10.1016/j.jas.2010.01.020

Baumgardner, R. W., Jr., DiMichele, W. A., and de Siqueira Vieira, N. (2016). An early Permian coastal flora dominated by Germaropteris martinsii from basinal sediments in the Midland Basin, West Texas. Palaeogeogr. Palaeoclimatol. Palaeoecol. 459, 409-422. doi:10.1016/j.palaeo.2016.07.024

Benca, J. P., Duijnstee, I., and Looy, C. V. (2018). UV-B-induced forest sterility: implications of ozone shield failure in Earth's largest extinction. Sci. Adv. 4, e1700618. doi:10.1126/sciadv.1700618

Benton, M. J., and Newell, A. J. (2014). Impacts of global warming on Permian-Triassic terrestrial ecosystems. Gondwana Res. 25, 1308-1337. doi:10.1016/j.gr.2012.12.010

Bercovici, A., Cui, Y., Forel, M., Yu, J., and Vajda, V. (2015). Terrestrial paleoenvironment characterization across the Permian-Triassic boundary in South China. J. Asian Earth Sci. 98, 225-246. doi:10.1016/j.jseaes.2014.11.016

Bodí, M. B., Martin, D. A., Balfour, V. N., Santín, C., Doerr, S. H., Pereira, P., et al. (2014). Wildland fire ash: production, composition and eco-hydro-geomorphic effects. Earth Sci. Rev. 130, 103-127. doi:10.1016/j.earscirev.2013.12.007

\section{DATA AVAILABILITY STATEMENT}

The raw data supporting the conclusions of this article will be made available by the authors, without undue reservation.

\section{AUTHOR CONTRIBUTION}

$\mathrm{ZF}$ conceived the project and designed the experiments. ZF, HBW, XDG and YG conducted the fieldwork. ZF, HBW, RHY, QS and LUL performed the experiments. ZF, HBW, YG, and SLY analyzed the data; ZF wrote the manuscript with input from other authors; all authors contributed to the discussion and approved the final manuscript.

\section{FUNDING}

This study was jointly supported by the National Natural Science Foundation of China (U1702242, 41762002, 41603035), the Strategic Priority Research Program of Chinese Academy of Sciences (XDB26000000), the Yunnan Provincial Science and Technology Department (2019FJ010, 2018FD008), the China Geological Survey (DD20190022), and the Key Research Program of the Institute of Geology and Geophysics, Chinese Academy of Sciences (IGGCAS-201905).

\section{ACKNOWLEDGMENTS}

We thank Prof. Hans Kerp and Wei-Dong Ren for insightful discussions, and André Jasper and Stephen McLoughlin for constructive comments.

Bond, W. J., and Keeley, J. E. (2005). Fire as a global 'herbivore': the ecology and evolution of flammable ecosystems. Trends Ecol. Evol. 20, 387-394. doi:10.1016/ j.tree.2005.04.025

Bond, W. J., and Scott, A. C. (2010). Fire and the spread of flowering plants in the Cretaceous. New Phytol. 188, 1137-1150. doi:10.1111/j.1469-8137.2010.03418.x

Bowman, D. M. J. S., Balch, J. K., Artaxo, P., Bond, W. J., Carlson, J. M., Cochrane, M. A., et al. (2009). Fire in the Earth system. Science 324, 481-484. doi:10.1126/ science. 1163886

Bureau of Geology and Mineral Resources of Yunnan Province (1996). Multiple classification and correlation of the stratigraphy of China (53), stratigraphy (lithostratic) of Yunnan province. Wuhan, China: China University of Geosciences Press, 728 [In Chinese].

Cai, Y.-f., Zhang, H., Feng, Z., Cao, C.-q., and Zheng, Q.-f. (2019). A germaropterisdominated flora from the upper Permian of the Dalongkou section, Xinjiang, Northwest China, and its palaeoclimatic and palaeoenvironmental implications. Rev. Palaeobot. Palynol. 266, 61-71. doi:10.1016/j.revpalbo.2019.01.006

Chen, J. H., Yu, J. X., Huang, Q. S., Broutin, J., Song, Q. Q., and Chen, B. (2011). New research progress on the paleoflora in the earliest Triassic of western Guizhou and eastern Yunnan, South China. Earth Sci. J. China Uni. Geosci. 36, 500-510 [In Chinese with English abstract]. doi:10.3799/dqkx.2011.051

Chu, D., Tong, J., Benton, M. J., Yu, J., and Huang, Y. (2019). Mixed continental-marine biotas following the Permian-Triassic mass extinction in south and north China. Palaeogeogr. Palaeoclimatol. Palaeoecol. 519, 95-107. doi:10.1016/j.palaeo.2017.10.028

Chu, D., Yu, J., Tong, J., Benton, M. J., Song, H., Huang, Y., et al. (2016). Biostratigraphic correlation and mass extinction during the Permian- 
Triassic transition in terrestrial-marine siliciclastic settings of south China. Glob. Planet. Change 146, 67-88. doi:10.1016/j.gloplacha.2016.09.009

Chu, D. L., Grasby, S. E., Song, H. J., Dal Corso, J., Wang, Y., Mather, T. A., et al. (2020). Ecological disturbance in tropical peatlands prior to marine PermoTriassic mass extinction. Geology 48, 288-292. doi:10.1130/g46631.1

Cui, Y., and Kump, L. R. (2015). Global warming and the end-Permian extinction event: proxy and modeling perspectives. Earth Sci. Rev. 149, 5-22. doi:10.1016/j. earscirev.2014.04.007

DiMichele, W. A., Kerp, H., Krings, M., and Chaney, D. S. (2005). “The Permian peltasperm radiation: evidence from the southwestern United States," in The nonmarine Permian. Editors S. G. Lucas and K. E. Zeigler (Albuquerque, NM: New Mexico Museum of Natural History and Science) Bulletin 30, 67-79.

Erwin, D. H. (2006). Extinctions: how life on Earth nearly ended 250 Million years ago. Princeton, NJ: Princeton University Press, 296.

Feng, Z. (2017). Late palaeozoic plants. Curr. Biol. 27, R905-R909. doi:10.1016/j. cub.2017.07.041

Feng, Z., Wei, H. B., Guo, Y., He, X. Y., Sui, Q., Zhou, Y., et al. (2020). From rainforest to herbland: new insights into land plant responses to the endPermian mass extinction. Earth Sci. Rev. 204, 103153. doi:10.1016/j.earscirev. 2020.103153

Geinitz, H. B. (1862). Dyas oder die Zechsteinformation und das Rothliegende: Die Pflanzen der Dyas und Geologisches. Leipzig, Germany: Wilhelm Engelmann Verlag, Vol. 2, 342.

Germar, E. F. (1840). Die Versteinerungen des Mansfelder Kupferschiefers. Halle, Germany: Eduard Anton, 39.

Glasspool, I. J. (2000). A major fire event recorded in the mesofossils and petrology of the Late Permian, Lower Whybrowcoal seam, Sydney Basin, Australia. Palaeogeogr. Palaeoclimatol. Palaeoecol. 164, 373-396. doi:10.1016/s00310182(00)00194-2

Glasspool, I. J., Edwards, D., and Axe, L. (2004). Charcoal in the Silurian as evidence for the earliest wildfire. Geology 32, 381-383. doi:10.1130/g20363.1

Glasspool, I. J., and Scott, A. C. (2013). "Identifying past fire events," in Fire phenomena and the earth system: an interdisciplinary guide to fire science. 1st Edn. Editor C. M. Belcher (Hoboken, NJ: Wiley-Blackwell, John Wiley \& Sons, Ltd.), 179-206.

Glasspool, I. J., Scott, A. C., Waltham, D., Pronina, N., and Shao, L. (2015). The impact of fire on the Late Paleozoic Earth system. Front. Plant Sci. 6, 756. doi:10. 3389/fpls.2015.00756

Goman'kov, A. V. (2006). A new species of the genus Lepidopteris (Peltaspermaceae, Peltaspermales) from the upper permian of the Russian platform. Bot. Zhu. 91, 1906-1914 [In Russian].

Grasby, S. E., Beauchamp, B., Bond, D. P. G., Wignall, P., Talavera, C., Galloway, J. M., et al. (2015). Progressive environmental deterioration in northwestern Pangea leading to the latest Permian extinction. Geol. Soc. Am. Bull. 127, 1331-1347. doi:10.1130/b31197.1

Grasby, S. E., Sanei, H., and Beauchamp, B. (2011). Catastrophic dispersion of coal fly ash into oceans during the latest Permian extinction. Nat. Geosci. 4, 104-107. doi:10.1038/ngeo1069

Harris, T. M. (1937). The fossil flora of Scoresby Sound, East Greenland, part 5: stratigraphic relations of the plant beds. Meddelelser Grønland 113, 1-112.

Holdgate, G. R., McLoughlin, S., Drinnan, A. N., Finkelman, R. B., Willett, J. C., and Chiehowsky, L. A. (2005). Inorganic chemistry, petrography and palaeobotany of permian coals in the prince Charles Mountains, East Antarctica. Int. J. Coal Geol. 63, 156-177. doi:10.1016/j.coal.2005.02.011

Holmes, W. B. K., and Anderson, H. M. (2005). The Middle Triassic megafossil flora of the Basin Creek formation, nymboida coal measures, New South Wales, Australia. Part 5. The genera Lepidopteris, Kurtziana, Rochipteris and Walkomiopteris. Proc. Linn. Soc. N. S. W. 126, 39-79.

Hochuli, P. A., Schneebeli-Hermann, E., Mangerud, G., and Bucher, H. (2017). Evidence for atmospheric pollution across the Permian-Triassic transition. Geology 45, 1123-1126. doi:10.1130/G39496.1

Hudspith, V., Scott, A. C., Collison, M. E., Pronina, N., and Beeley, T. (2012). Evaluating the extent to which wildfire history can be interpreted from inertinite distribution in coal pillars: an example from the Late Permian, Kuznetsk Basin, Russia. Int. J. Coal Geol. 89, 13-25. doi:10.1016/j.coal.2011. 07.009

Jasper, A., Guerra-Sommer, M., Uhl, D., Bernardes-de-Oliveira, M. E. C., Tewari, R., and Secchi, M. I. (2012). Palaeobotanical evidence of wildfires in the Upper permian of India: macroscopic charcoal remains from the Raniganj formation, damodar valley Basin. Palaeobotanist 61, 75-82.

Jasper, A., Uhl, D., Agnihotri, D., Tewari, R., Pandita, S. K., Benicio, J. R. W., et al. (2016). Evidence of wildfires in the late permian (Changsinghian) Zewan Formation of Kashmir, India. Curr. Sci. 110, 419-423. doi:10.18520/cs/v110/ i3/419-423

Jasper, A., Uhl, D., Guerra-Sommer, M., Bernardes-de-Oliveira, M. E. C., and Machado, N. T. G. (2011). Upper Paleozoic charcoal remains from South America: Multiple evidences of fire events in the coal bearing strata of the Paraná Basin, Brazil. Palaeogeogr. Palaeoclimatol. Palaeoecol. 306, 205-218. doi:10.1016/j.palaeo.2011.04.022

Joachimski, M. M., Lai, X., Shen, S., Jiang, H., Luo, G., and Chen, J. (2012). Climatic warming in the latest Permian and the Permian-Triassic mass extinction. Geology 40, 195-198. doi:10.1130/g32707.1

Jones, T. P., Scott, A. C., and Cope, M. (1991). Reflectance measurements and the temperature of formation of modern charcoals and implications for studies of fusain. Bull. Soc. Geol. Fr. 162, 193-200.

Kerp, H. (1996). Post-variscan late palaeozoic northern hemisphere gymnosperms: the onset to the Mesozoic. Rev. Palaeobot. Palynol. 90, 263-285. doi:10.1016/ 0034-6667(95)00087-9

Kerp, H. (2000). The modernization of landscapes during the late paleozoic-early Mesozoic. Paleontol. Soc. Pap. 6, 79-114. doi:10.1017/S1089332600000723

Kerp, H., Broutin, J., Lausberg, S., and Aassoumi, H. (2001). Discovery of latest Carboniferous-early permian radially symmetrical peltaspermaceous megasporophylls from europe and north Africa. Comptes Rendus l'Acad. Sci. Ser. II A Earth Planet. Sci. 332, 513-519. doi:10.1016/s1251-8050(01) 01559-2

Knoll, A. H., Bambach, R. K., Payne, J. L., Pruss, S., and Fischer, W. W. (2007). Paleophysiology and end-Permian mass extinction. Earth Planet. Sci. 256 295-313. doi:10.1016/j.epsl.2007.02.018

Kurtze, G. A. (1839). Commentatio de petrefactis quae in schisto bituminoso mansfeldensi reperiuntur. Halle, Germany: Anton, 38.

Kustatscher, E., Bauer, K., Butzmann, R., Fischer, T. C., Meller, B., van Konijnenburg-van Cittert, J. H. A., et al. (2014). Sphenophytes, pteridosperms and possible cycads from the Wuchiapingian (Lopingian, Permian) of Bletterbach (Dolomites, Northern Italy). Rev. Palaeobot. Palynol. 208, 65-82. doi:10.1016/j.revpalbo.2014.05.003

Li, X. X. (1997). The origin, evolution and distribution of the Cathaysian flora. Acta Palaeontol. Sin. 36, 411-422 [In Chinese with English summary]

Liu, F., Zhu, H. C., and Ouyang, S. (2011). Taxonomy and biostratigraphy of Pennsylvanian to late Permian megaspores from Shanxi, North China. Rev. Palaeobot. Palynol. 165, 135-153. doi:10.1016/j.revpalbo.2011.03.001

Liu, F., Zhu, H. C., and Ouyang, S. (2015). Late Pennsylvanian to Wuchiapingian palynostratigraphy of the Baode section in the Ordos Basin, North China. J. Asian Earth Sci. 111, 528-552. doi:10.1016/j.jseaes.2015.06.013

Liu, L. J., and Yao, Z. Q. (2000). The earliest Permian Peltaspermum and some gymnospermous seeds from the southern border of the Turpan-Hami Basin of Xinjiang, China. Acta Palaeontol. Sin. 39, 110-118 [In Chinese with English summary].

Mays, C., Vajda, V., Frank, T. D., Fielding, C. R., Nicoll, R. S., Tevyaw, A. P., et al. (2020). Refined Permian-Triassic floristic timeline reveals early collapse and delayed recovery of south polar terrestrial ecosystems. GSA Bull. 132, 1489-1513. doi:10.1130/b35355.1

McElwain, J. C., and Punyasena, S. W. (2007). Mass extinction events and the plant fossil record. Trends Ecol. Evol. 22, 548-557. doi:10.1016/j.tree.2007.09. 003

McLoughlin, S., Maksimenko, A., and Mays, C. (2019). A new high-paleolatitude permineralized peat flora from the late Permian of the Sydney Basin, Australia. Int. J. Plant Sci. 180, 513-539. doi:10.1086/702939

McParland, L. C., Collinson, M. E., Scott, A. C., Steart, D. C., Grassineau, N. V., and Gibbons, S. J. (2007). Ferns and fires: experimental charring of ferns compared to wood and implications for paleobiology, paleoecology, coal petrology, and isotope geochemistry. Palaios 22, 528-538. doi:10.2110/palo. 2005.p05-138r

Midgley, J. J., and Bond, W. J. (2013). "Plant adaptations to fire: an evolutionary perspective," in Fire phenomena and the earth system: an interdisciplinary guide to fire science. 1st Edn, Editor C. M. Belcher (Hoboken, NJ: Wiley-Blackwell, John Wiley \& Sons, Ltd.), 125-134. 
Němejc, F. (1968). Palaeobotanika III. Praha, Slovakia: Academia, 474.

Pausas, J. G., and Bond, W. J. (2020). On the three major recycling pathways in terrestrial ecosystems. Trends Ecol. Evol. 35, 767-775. doi:10.1016/j.tree.2020.04.004

Poort, R. J., and Kerp, J. H. F. (1990). Aspects of Permian palaeobotany and palynology. XI. On the recognition of true peltasperms in the Upper Permian of Western and Central Europe and a reclassification of species formerly included in Peltaspermum Harris. Rev. Palaeobot. Palynol. 63, 197-225. doi:10.1016/ 0034-6667(90)90100-w

Retallack, G. J. (2002). Lepidopteris callipteroides, an earliest Triassic seed fern from the Sydney Basin, southeastern Australia. Alcheringa 26, 475-500. doi:10.1080/ 03115510208619538

Retallack, G. J. (2018). Leaf preservation in Eucalyptus woodland as a model for sclerophyll fossil floras. Alcheringa 43, 71-84. doi:10.1080/03115518.2018.1457180

Romano, C., Goudemand, N., Vennemann, T. W., Ware, D., Schneebeli-Hermann, E., Hochuli, P. A., et al. (2013). Climatic and biotic upheavals following the endPermian mass extinction. Nat. Geosci. 6, 57-60. doi:10.1038/ngeo1667

Scholze, F., Shen, S. Z., Backer, M., Wei, H. B., Hübner, M., Cui, Y. Y., et al. (2020). Reinvestigation of conchostracans (Crustacea: Branchiopoda) from late Permian-early Triassic sections in South China. Palaeoworld 29, 368-390. doi:10.1016/j.palwor.2019.04.007

Schweitzer, H. J. (1962). Die Makroflora des niederrheinischen Zechstein. Fortschritte Geol. Rheinlandes Westfalens 6, 1-46.

Scott, A. C. (2009). "Forest fire in the fossil record," in Fire effects on soils and restoration strategies. Editors A. Cerdà and P. Robichaud (Enfield, NH: Science Publishers, Inc.), 1-37.

Scott, A. C. (2010). Charcoal recognition, taphonomy and uses in palaeoenvironmental analysis. Palaeogeogr. Palaeoclimatol. Palaeoecol. 291, 11-39. doi:10.1016/j.palaeo.2009.12.012

Scott, A. C., Cripps, J. A., Collinson, M. E., and Nichols, G. J. (2000). The taphonomy of charcoal following a recent heathland fire and some implications for the interpretation of fossil charcoal deposits. Palaeogeogr. Palaeoclimatol. Palaeoecol. 164, 1-31. doi:10.1016/s0031-0182(00)00168-1

Scott, A. C., and Glasspool, I. J. (2005). Charcoal reflectance as a proxy for the emplacement temperature of pyroclastic flow deposits. Geology 33, 589-592. doi:10.1130/g21474.1

Scott, A. C., and Glasspool, I. J. (2007). Observations and experiments on the origin and formation of inertinite group macerals. Int. J. Coal Geol. 70, 55-66. doi:10. 1016/j.coal.2006.02.009

Scott, A. C., and Jones, T. J. (1994). The nature and influence of fires in Carboniferous ecosystems. Palaeogeogr. Palaeoclimatol. Palaeoecol. 106, 91-112. doi:10.1016/0031-0182(94)90005-1

Shao, L., Wang, H., Yu, X., Lu, J., and Zhang, M. (2012). Paleo-fires and atmospheric oxygen levels in the latest Permian: evidence from maceral compositions of coals in eastern Yunnan, southern China. Acta Geol. Sin. 86, 949-962. doi:10.1111/j.1755-6724.2012.00719.x

Shen, S., Zhang, H., Zhang, Y., Yuan, D., Chen, B., He, W., et al. (2019). Permian integrative stratigraphy and timescale of China. Sci. China Earth Sci. 62, 154-188. doi:10.1007/s11430-017-9228-4

Shen, S. Z., and Bowring, S. A. (2014). The end-Permian mass extinction: a still unexplained catastrophe. Natl. Sci. Rev. 1 (4), 492-495. doi:10.1093/nsr/nwu047

Shen, S.-z., Crowley, J. L., Wang, Y., Bowring, S. A., Erwin, D. H., Sadler, P. M., et al. (2011). Calibrating the end-Permian mass extinction. Science 334, 1367-1372. doi:10.1126/science.1213454

Shen, W., Sun, Y., Lin, Y., Liu, D., and Chai, P. (2011). Evidence for wildfire in the Meishan section and implications for Permian-Triassic events. Geochem. Cosmochim. Acta 75, 1992-2006. doi:10.1016/j.gca.2011.01.027

Stanislavsky, F. A. (1976). Middle Keuper flora of the Donetz basin. Ukraine, Kiev: Naukova Dumka, 168 [In Russian].

Stoneley, H. M. M. (1958). The Upper permian flora of England. Bulletin of the British Museum (natural history), Geology 3, 293-337.

Su, Y., Joachimski, M. M., Wignall, P. B., Yan, C., Chen, Y., Jiang, H., et al. (2012). Lethally hot temperatures during the early Triassic greenhouse. Science 338, 366-370. doi:10.1126/science.1224126

Taylor, T. N., Taylor, E. L., and Krings, M. (2009). Paleobotany: the biology and evolution of fossil plants. 2nd Edn. Amsterdam, Netherlands: Academic Press, 1230.

Townrow, J. A. (1956). The genus Lepidopteris and its southern hemisphere species. Avhandlinger Utgitt av det norske Videnskaps-Akademi I Oslo. I. Math. Naturwiss. Klasse 2, 3-28.
Townrow, J. A. (1960). The Peltaspermaceae, a pteridosperm family of Permian and Triassic age. Palaeontology 3, 333-361. doi:10.1080/ 00222936008655769

Uhl, D., Abu Hamad, A. M. B., Kerp, H., and Bandel, K. (2007). Evidence for palaeo-wildfire in the late permian palaeotropics-charcoalified wood from the Um Irna Formation of Jordan. Rev. Palaeobot. Palynol. 144, 221-230. doi:10. 1016/j.revpalbo.2006.08.003

Uhl, D., Butzmann, R., Fischer, T. C., Meller, B., and Kustatscher, E. (2012). Wildfires in the late palaeozoic and Mesozoic of the southern Alps-the late permian of the Bletterbach-Butterloch area (Northern Italy). Riv. Ital. Paleontol. Stratigr. 118, 223-233. doi:10.13130/2039-4942/6002

Uhl, D., and Kerp, H. (2003). Wildfires in the late palaeozoic of Central europe-the Zechstein (Upper permian) of NW-Hesse (Germany) Palaeogeogr. Palaeoclimatol. Palaeoecol. 199, 1-15. doi:10.1016/s00310182(03)00482-6

Vajda, V., McLoughlin, S., Mays, C., Frank, T. D., Fielding, C. R., Tevywa, A., et al. (2020). End-Permian (252 Mya) deforestation, wildfires and flooding-an ancient biotic crisis with lessons for the present. Earth Planet Sci. Lett. 529, 115875. doi:10.1016/j.epsl.2019.115875

Vörding, B., and Kerp, H. (2008). Stomatal indices of Peltaspermum martinsi (pteridospermopsida, Peltaspermaceae) from the upper Permian Bletterbach Gorge and their possible applicability as $\mathrm{CO}_{2}$ proxies. Neues Jahrbuch Geol. Palaontol. Abhand. 248, 245-255. doi:10.1127/0077-7749/2008/0248-0245

Wan, M., and Wang, J. (2015). Nanshanopteris nervosa gen. et sp. nov., a glenopterid foliage from the Changhsingian Sunan Formation in Yumen, western China. Rev. Palaeobot. Palynol. 219, 39-51. doi:10.1016/j.revpalbo. 2015.03.009

Wang, J., Kerp, H., and Pfefferkorn, H. W. (2014). The earliest occurrence of peltasperms in the basal Permian strata of the North China Block and the radiation of this group. Geol. J. 49, 129-142. doi:10.1002/gj.2503

Wang, Z. Q. (1985). Palaeovegetation and plate tectonics: palaeophytogeography of north China during Permian and Triassic times. Palaeogeogr. Palaeoclimatol. Palaeoecol. 49, 25-45. doi:10.1016/0031-0182(85)90003-3

Wang, Z. Q., and Chen, A. S. (2001). Traces of arborescent lycopsids and dieback of the forest vegetation in relation to the terminal Permian mass extinction in North China. Rev. Palaeobot. Palynol. 117, 217-243. doi:10.1016/s00346667(01)00094-x

Wang, Z. Q., and Wang, L. X. (1986). Late Permian fossil plants from the lower part of the Shiqianfeng (Shihchienfeng) group in north China. Bull. Tianjing Inst. Geol. Mineral. Res. 15, 1-120 [In Chinese with English abstract].

Wignall, P. B. (2015). The worst of times how life on Earth survived eighty million Years of extinctions. Princeton, NJ: Princeton University Press, 224.

Yan, M., Wan, M., He, X., Hou, X., and Wang, J. (2016). First report of Cisuralian (early Permian) charcoal layers within a coal bed from Baode, North China with reference to global wildfire distribution. Palaeogeogr. Palaeoclimatol. Palaeoecol. 459, 394-408. doi:10.1016/j.palaeo.2016.07.031

Yu, J., Broutin, J., Chen, Z. Q., Shi, X., Li, H., Chu, D., et al. (2015). Vegetation changeover across the Permian-Triassic boundary in Southwest China extinction, survival, recovery and palaeoclimate: a critical review. Earth Sci. Rev. 149, 203-224. doi:10.1016/j.earscirev.2015.04.005

Zhang, H., Cao, C. Q., Liu, X. L., Mu, L., Zheng, Q. F., Liu, F., et al. (2016). The terrestrial end-Permian mass extinction in South China. Palaeogeogr. Palaeoclimatol. Palaeoecol. 448, 108-124. doi:10.1016/j.palaeo.2015.07.002

Zhang, Y., Zheng, S., and Naugolnykh, S. V. (2012). A new species of Lepidopteris discovered from the upper Permian of China with its stratigraphic and biologic implications. Chin. Sci. Bull. 57, 3603-3609. doi:10.1007/s11434-012-5282-0

Conflict of Interest: The authors declare that the research was conducted in the absence of any commercial or financial relationships that could be construed as a potential conflict of interest.

Copyright $\odot 2020$ Feng, Wei, Ye, Sui, Gou, Guo, Liu and Yang. This is an openaccess article distributed under the terms of the Creative Commons Attribution License (CC BY). The use, distribution or reproduction in other forums is permitted, provided the original author(s) and the copyright owner(s) are credited and that the original publication in this journal is cited, in accordance with accepted academic practice. No use, distribution or reproduction is permitted which does not comply with these terms. 


\section{APPENDIX}

\section{Systematic Paleobotany}

Order Peltaspermales Němejc, 1968.

Family Peltaspermaceae Thomas ex Harris, 1937.

Genus Germaropteris Kustatscher et al. (2014).

Species Germaropteris martinsii (Germar in Kurtze 1839) Kustatscher et al., 2014.

\section{Selected Synonyms}

1985 Callipteris martinsii, Wang, Palaeogeogr. Palaeoclimatol.

Palaeoecol., 49, pl. II, 1-6.

1986 Callipteris martinsii, Wang and Wang, Tianjin Inst. Geol. Min. Res. 15, pl. VI, 1, 2; pl. IX, 1-7; pl. X, 1-7; pl. $\mathrm{XI}, 1$.
1986 Callipteris papillosa, Wang and Wang, Tianjin Inst. Geol. Min. Res. 15, pl. V, 13; pl. VI, 3-9; pl. VII, 1-7; pl. VIII, 1-7; pl. XI, 9-11. 1986 Callipteris lobulata, Wang and Wang, Tianjin Inst. Geol. Min. Res. 15, pl. XI, 2-7; pl. XII, 1-6; pl. XIII, 1-10; pl. XIV, 1-9. 2011 Peltaspermum martinsii, Chen et al., Earth Sci. J. China Uni. Geosci. 36 (3), pl. II, 1-3.

2012 Lepidopteris baodensis, Zhang et al., Chinese Sci. Bull. 57 (27), Figures 2, 3.

2015 Lepidopteris cf. martinsii, Bercovici et al., J. Asian Earth Sci. 98, Figure 7G.

2015 Peltaspermum cf. martinsii, Yu et al., Earth-Sci. Rev. 149, Figures 12A-D.

2016 Peltaspermum cf. martinsii, Chu et al., Global Planet. Change 146, Figure $11(10,11)$.

2019 Peltaspermum cf. martinsii, Chu et al., Palaeogeogr. Palaeoclimatol. Palaeoecol. 519, Figures 6A-D. 